ARTICLE

Received 27 Aug 2015 | Accepted 27 Nov 2015 | Published 18 Jan 2016

DOI: $10.1038 /$ ncomms10308

OPEN

\title{
Insertion compounds and composites made by ball milling for advanced sodium-ion batteries
}

Biao Zhang ${ }^{1,2,3}$, Romain Dugas ${ }^{1,2,3}$, Gwenaelle Rousse ${ }^{1,2,3,4}$, Patrick Rozier ${ }^{2,3,5}$, Artem M. Abakumov ${ }^{6,7}$ \& Jean-Marie Tarascon 1,2,3,4

Sodium-ion batteries have been considered as potential candidates for stationary energy storage because of the low cost and wide availability of $\mathrm{Na}$ sources. However, their future commercialization depends critically on control over the solid electrolyte interface formation, as well as the degree of sodiation at the positive electrode. Here we report an easily scalable ball milling approach, which relies on the use of metallic sodium, to prepare a variety of sodium-based alloys, insertion layered oxides and polyanionic compounds having sodium in excess such as the $\mathrm{Na}_{4} \mathrm{~V}_{2}\left(\mathrm{PO}_{4}\right)_{2} \mathrm{~F}_{3}$ phase. The practical benefits of preparing sodiumenriched positive electrodes as reservoirs to compensate for sodium loss during solid electrolyte interphase formation are demonstrated by assembling full $\mathrm{C} / \mathrm{P}^{\prime} 2-\mathrm{Na}_{1}\left[\mathrm{Fe}_{0.5} \mathrm{Mn}_{0.5}\right] \mathrm{O}_{2}$ and $\mathrm{C} / \mathrm{Na}_{3+x} \mathrm{~V}_{2}\left(\mathrm{PO}_{4}\right)_{2} \mathrm{~F}_{3}$ ' sodium-ion cells that show substantial increases $(>10 \%)$ in energy storage density. Our findings may offer electrode design principles for accelerating the development of the sodium-ion technology.

\footnotetext{
${ }^{1}$ Chimie du Solide-Energie, FRE 3677, Collège de France, 11 Place Marcelin Berthelot, Paris, Cedex 0575231 , France. ${ }^{2}$ Réseau sur le Stockage Electrochimique de I'Energie (RS2E), FR CNRS 3459, Amiens 80039, France. ${ }^{3}$ ALISTORE-European Research Institute, Amiens 80039 , France. ${ }^{4}$ Sorbonne Universités_UPMC Univ Paris 06, 4 Place Jussieu, Paris F-75005, France. ${ }^{5}$ University of Toulouse III Paul Sabatier, CIRIMAT CNRS UMR 5085, 118 route de Narbonne, Toulouse, Cedex 09 31062, France. ${ }^{6}$ EMAT, University of Antwerp, Groenenborgerlaan 171, Antwerp B-2020, Belgium.

7 Skolkovo Institute of Science and Technology, Moscow 143025, Russia. Correspondence and requests for materials should be addressed to J.-M.T. (email: jean-marie.tarascon@college-de-france.fr).
} 
C onsidering elemental abundance, the most appealing alternative to Li-based battery technology is undoubtedly sodium. This is reflected in the revival of Na-ion battery (NIB) research, a field in which intense efforts are currently devoted to the search for high-performance electrode materials. Progress in sodium intercalation chemistry is primarily inherited from work on Li-ion materials, with the negative and positive electrodes for sodium systems based on similar structural types $^{1-3}$. For negative electrodes comprising sodium metal, $\mathrm{Na}_{x} \mathrm{Sb}$ is the most attractive ${ }^{4}$. Antimony, however, is not the most desirable component considering its scarcity, moderate toxicity and large mass. There is thus great interest in carbon negative electrodes, whose reversible capacity can reach $300 \mathrm{mAhg}^{-1}$ after accounting for a $\sim 25 \%$ irreversibility penalty associated with formation of the solid electrolyte interface (SEI) in the first cycle ${ }^{5}$. Among the positive electrode candidates, polyanionic compounds such as $\mathrm{Na}_{3} \mathrm{~V}_{2}\left(\mathrm{PO}_{4}\right)_{2} \mathrm{~F}_{3}$ (NVPF) (refs 6,7) and $\mathrm{Na}_{2} \mathrm{Fe}_{2}\left(\mathrm{SO}_{4}\right)_{3}$ (ref. 8), and layered compounds like the $\mathrm{O} 3-\mathrm{NaNi}_{0.5} \mathrm{Mn}_{0.5} \mathrm{O}_{2}$ (ref. 9) and $\mathrm{P} 2-\mathrm{Na}_{0.67}\left[\mathrm{Fe}_{0.5} \mathrm{Mn}_{0.5}\right] \mathrm{O}_{2}$ (ref. 10 ) phases are presently the most studied. Nevertheless, the performances of NIB prototypes based on the aforementioned materials suffer from the large irreversibility of initial Na-uptake-removal processes at the carbon negative electrode.

The sodium loss in the formation of the SEI is similar to what is observed in the case of Li-ion batteries (LIBs), which has been widely studied. Because the only source of $\mathrm{Li}$ in the $\mathrm{Li}$-ion cell is the Li-bearing electrode, compensating for lithium loss in the formation of the SEI at the negative electrode has been of great importance for achieving high energy densities in LIBs, and it is becoming more urgent with the emerging $\mathrm{Si}$ anodes, which show larger initial irreversibility than carbon electrodes. Through the years various routes have been explored. By adding to the positive electrode either sacrificial lithium species or additional intercalation compounds, the full capacity of a cathode material can be realized with modest weight penalties, For example, $\mathrm{Li}_{2} \mathrm{C}_{2} \mathrm{O}_{4}$ is used as a sacrificial source that decomposes during oxidation to provide extra lithium ${ }^{11}$. Alternately, in compounds such as $\mathrm{Li}_{1+x} \mathrm{Mn}_{2} \mathrm{O}_{4}$, which contains two redox voltages, the low-voltage $\sim 3 \mathrm{~V}$ plateau associated with $x \mathrm{Li}^{+}$can be used as a $\mathrm{Li}$ reservoir ${ }^{12}$. Another approach, mainly applied to $\mathrm{Si}$, is in situ or ex situ pre-lithiation. This can be accomplished either by $\mathrm{Li}$ ball milling ${ }^{13}$, or by placing $\mathrm{Si}$ in contact with $\mathrm{Li}$ so that when electrolyte is added formation of the SEI occurs conjointly with the uptake of $\mathrm{Li}$ by the negative $\mathrm{Si}$ electrode $\left(\mathrm{Li}_{x} \mathrm{Si}\right.$ ) (ref. 14).

Considering the lower coulombic efficiency of hard carbon in NIBs, that is, $<80 \%$ (ref. 15), a strategy to compensate for Na loss to the SEI is sorely needed. It is also equally important to tune the degree of sodiation in cathodes to be used in NIBs, especially in the case of 'sodium deficient' P2-type layered oxide electrodes of formula $\mathrm{Na}_{2 / 3} \mathrm{MO}_{2}(\mathrm{M}=\mathrm{Mn}, \mathrm{Fe}, \mathrm{Co} . . .)^{10,16}$, which only contain $\sim 0.67 \mathrm{Na}^{+}$per formula unit. These materials can achieve performances as high as $200 \mathrm{mAhg}^{-1}$ but only in half cells against sodium metal which, in excess, enables $\mathrm{NaMO}_{2}$ compositions to be reached upon cycling. In contrast, the capacity drops by $30 \%$ in $\mathrm{Na}$-ion cells because of the lack of a $\mathrm{Na}$ reservoir to compensate for the missing $0.33 \mathrm{Na}^{+}$in the pristine $\mathrm{P} 2$ phase. Solving these two issues constitutes the driving force of the present study.

Surprisingly few studies have been conducted before now to address the development of $\mathrm{Na}$ reservoir sources and presodiation reagents for NIBs while minimizing energy penalty. Recently, $\mathrm{NaN}_{3}$ was proposed as a sacrificial Na source, but the generation of $\mathrm{N}_{2}$ gas during its non-reversible electrochemically driven decomposition upon oxidation is detrimental to the battery. Moreover, the low $\mathrm{Na}$ content in $\mathrm{NaN}_{3}$ (35\% $\mathrm{Na}$ by weight) imposes a penalty in energy density ${ }^{17}$. Similar to LIBs, $\mathrm{Na}$ metal would obviously be the best pre-sodiation reagent for NIBs. However, it is one of the most difficult metals to handle because of its ductility and tendency to stick to metallic surfaces. Following our previous work on preparing Li-alloy through ball milling ${ }^{18}$, we report herein the synthesis of Na-based alloys and other insertion compounds via the ball milling of Na-metal with the appropriate chemical elements. We find this approach equally suitable for tuning the amount of $\mathrm{Na}$ in insertion electrodes. In particular, we find that $\mathrm{Na}_{3} \mathrm{P}$-the $\mathrm{Na}$-based compound showing the closest capacity $\left(804 \mathrm{mAh} \mathrm{g}^{-1}\right)$ to $\mathrm{Na}$ metal $\left(1,165 \mathrm{mAh}^{-1}\right)$ and hence offering the minimum weight penalty-can be used as a sacrificial $\mathrm{Na}$ source, increasing for instance the reversible capacity of $\mathrm{C} / \mathrm{P}^{\prime} 2-\mathrm{Na}\left[\mathrm{Fe}_{0.5} \mathrm{Mn}_{0.5}\right] \mathrm{O}_{2}$ cells by $20 \%$. We begin by describing the ball milling synthesis of $\mathrm{Na}$-alloys, then present the use of the Na-ball milling approach for pre-sodiation of insertion positive electrodes ( $\left.\mathrm{P} 2-\mathrm{Na}_{0.67}\left[\mathrm{Fe}_{0.5} \mathrm{Mn}_{0.5}\right] \mathrm{O}_{2}, \mathrm{NVPF}\right)$, and end with the implementation of both approaches towards the optimization of full $\mathrm{Na}$-ion cells.

\section{Results}

Ball milling-driven formation of Na-based alloys. $\mathrm{Na}_{3} \mathrm{P}$ powders were prepared by adding stoichiometric amounts of Na-lumps and red phosphorous powder into a hardened steel ball milling jar, loaded in an Ar-filled glove box, with a ball/powder weight ratio of 35. Strikingly, room temperature continuous ball milling for $2 \mathrm{~h}$, using a SPEX 8000 milling apparatus, was found to be sufficient to produce well crystalline and single-phased $\mathrm{Na}_{3} \mathrm{P}$ powders as deduced by X-ray diffraction (XRD) (Fig. 1a,b), while shear grinding for $27 \mathrm{~h}$ in planetary ball mill was shown to give a mixture of $\mathrm{Na}_{3} \mathrm{P}$ and amorphous phase ${ }^{19}$. These powders were mixed with carbon SP (30\% by weight) and further ball milled for $20 \mathrm{~min}$ to obtain homogeneous composite electrodes. When cycled versus $\mathrm{Na}^{+} / \mathrm{Na}^{0}$, these composites showed reversible capacity (Fig. 1c) of $\sim 600 \mathrm{mAh} \mathrm{g}^{-1}$ based on the weight of $\mathrm{Na}_{3} \mathrm{P}$.

To highlight the simplicity of this ball milling synthesis we recall the two approaches previously adopted to prepare $\mathrm{Na}_{3} \mathrm{P}$ powders: (i) electrochemical sodiation of $\mathrm{P}$ by making a battery using $\mathrm{P}$ and $\mathrm{Na}$ metal as working and counter electrode ${ }^{20}$, respectively; and (ii) chemical alloying of $\mathrm{Na}$ and $\mathrm{P}$, either through a solvothermal reaction at $150^{\circ} \mathrm{C}$ (ref. 21), or high temperature annealing $\left(480^{\circ} \mathrm{C}\right)$ in evacuated silica ampoules ${ }^{22}$. Encouraged by these results, we successfully extended the approach to the synthesis of $\mathrm{Na}_{x} \mathrm{M}$ alloys, where $\mathrm{M}$ is selected from the group consisting of $\mathrm{Sn}, \mathrm{Sb}$ and $\mathrm{Pb}$. For reasons of conciseness, the preparation of single-phase $\mathrm{Na}_{3} \mathrm{Sb}$ powders (Fig. 1d) whose voltage-composition curves fully mirror previous literature data (Fig. 1e) ${ }^{23}$ is solely reported herein.

Although speculative, we believe that the key to success for such unexpected reactions depends on the large free energy $(\Delta G)$ of the alloy formation reaction. As depicted in the schematic representations of Fig. 1a, a monolayer of alloy is rapidly created by contact of metal particles with $\mathrm{Na}$ lumps, hence separating the $\mathrm{Na}$ from the metal container and balls. Ball milling will continuously break the alloy shell to expose fresh surfaces, which rapidly react in a progressive alloying of all the $\mathrm{Na}$, most likely facilitated by local heating. The repeated alloying/fracturing sequences are accompanied by a continuous peeling and breaking of the alloy shell into loose powders.

Ball milling-driven pre-sodiation of insertion electrodes. The successful synthesis of $\mathrm{Na}$-based alloys by room temperature $\mathrm{Na}$ ball milling encouraged us to exploit the reducing power of both $\mathrm{Na}$ and $\mathrm{Na}_{3} \mathrm{P}$ to simulate electrochemical reduction of positive electrode materials so as to increase their sodium content. 
We tested this possibility using the P2-type layered oxide phase, $\mathrm{Na}_{0.67}\left[\mathrm{Fe}_{0.5} \mathrm{Mn}_{0.5}\right] \mathrm{O}_{2}$, which can be electrochemically reduced at a potential near $1.5 \mathrm{~V}$ to form the $\mathrm{P}^{\prime} 2-\mathrm{Na}_{1}\left[\mathrm{Fe}_{0.5} \mathrm{Mn}_{0.5}\right] \mathrm{O}_{2}$ phase that delivers a capacity of $\sim 190 \mathrm{mAhg}^{-1}$ (ref. 24). Attempts to synthesize $\mathrm{P}^{\prime} 2$ type $\mathrm{Na}_{1}\left[\mathrm{Fe}_{0.5} \mathrm{Mn}_{0.5}\right] \mathrm{O}_{2}$ through direct solid-state reaction have so far failed, resulting in an $\mathrm{O} 3$ type phase with poor capacity ${ }^{10}$. Stoichiometric amounts of $\mathrm{Na}_{0.67}\left[\mathrm{Fe}_{0.5} \mathrm{Mn}_{0.5}\right] \mathrm{O}_{2}$ (XRD shown in Fig. 2b) and $\mathrm{Na}$ metal were added under argon into a hardened steel ball milling jar using a ball to powder weight ratio of 35. The XRD pattern of the obtained powder (Fig. 2a) is consistent with the reflections reported for the electrochemically produced $\mathrm{P}^{\prime} 2$ phase ${ }^{24}$, which confirms the successful production of fully sodiated $\mathrm{P}^{\prime} 2-\mathrm{Na}_{1}\left[\mathrm{Fe}_{0.5} \mathrm{Mn}_{0.5}\right] \mathrm{O}_{2}$ after only $2 \mathrm{~h}$ of ball milling. At shorter milling time or when a sub-stoichiometric amount of $\mathrm{Na}$ is used, the ball-milled samples are a mixture of the $\mathrm{P} 2$ and $\mathrm{P}^{\prime} 2$ phases.

Fig. 2c-e compare the electrochemical behaviour of a $\mathrm{Na} / \mathrm{P} 2$ cell with that of a Na/ $\mathrm{P}^{\prime} 2$ cell with the $\mathrm{P}^{\prime} 2$ phase made by ball milling with $\mathrm{Na}$. Note that only $0.45 \mathrm{Na}^{+}$can be removed from the P2-based cell, as opposed to nearly $0.8 \mathrm{Na}^{+}$for the $\mathrm{P}^{\prime} 2$ cell, clearly confirming the success of the ball milling-induced sodiation process. Aside from this difference, the cells behave identically in terms of reversible and sustained capacity upon cycling, independently of whether pristine $\mathrm{P} 2$ or $\mathrm{P}^{\prime} 2$ obtained by $\mathrm{Na}$ ball milling was initially used.

In addition to layered oxides, the polyanionic compound NVPF $\left(\mathrm{Na}_{3} \mathrm{~V}_{2}\left(\mathrm{PO}_{4}\right)_{2} \mathrm{~F}_{3}\right)$ is also of great interest as a positive electrode in $\mathrm{Na}$-ion cells ${ }^{25,26}$ since it shows high-voltage plateaus near 3.6 and $4.2 \mathrm{~V}$, whose equal amplitudes provide a cumulative capacity of $\sim 110 \mathrm{mAhg}^{-1}$. To generalize our approach, we explored the ball milling-driven reactivity of $\mathrm{Na}$ against NVPF.
$\mathrm{Na}_{3} \mathrm{~V}_{2}\left(\mathrm{PO}_{4}\right)_{2} \mathrm{~F}_{3}$ powders were mixed with various amounts of $\mathrm{Na}$ and various ball milling times (Supplementary Fig. 1). To our surprise, ball milling 1 molar equivalent of NVPF with 2 equivalents of $\mathrm{Na}$ metal lumps for $30 \mathrm{~min}$ (ball to powder weight ratio of 35) results in loose composite powders whose XRD pattern differs from that of NVPF with namely the onset of extra peaks corresponding to the onset of a second phase. By increasing the milling time we progressively increase the amount of this extra phase, which was obtained as a single phase after $3 \mathrm{~h}$ of ball milling (Fig. 3a-c). The elemental distribution and chemical composition of this as-prepared powder was studied by high-angle annular dark field scanning transmission electron microscopy. The images demonstrate that crystallites of the main phase are surrounded by $\mathrm{Na}$ nanoparticles with sizes of 20-50 nm, as deduced from compositional energy-dispersive $\mathrm{X}$-ray spectroscopy mapping (Supplementary Fig. 2a,b). Note that this is in agreement with the residual amount of $\mathrm{Na}$ metal, as deduced by differential scanning calorimetry (DSC) (Supplementary Fig. 3). Moreover, the analysis of the main phase crystallites provides a Na:V:P =4.0(2):2.0(1):2.1(2) atomic ratio, consistent with a $\mathrm{Na}_{4} \mathrm{~V}_{2}\left(\mathrm{PO}_{4}\right)_{2} \mathrm{~F}_{3}$ formulae.

The Synchrotron XRD patterns of the pristine NVPF and $\mathrm{Na}_{4} \mathrm{~V}_{2}\left(\mathrm{PO}_{4}\right)_{2} \mathrm{~F}_{3}$ phase, and of a mixture of both phases are shown in Fig. $3 \mathrm{a}-\mathrm{c}$. The diffraction peaks of the phase formed upon ball milling with $\mathrm{Na}$ can be indexed in the same orthorhombic cell as for the pristine $\mathrm{NVPF}^{26}$, but with different lattice parameters, that is, $a=9.2208(2) \AA, b=9.2641(2) \AA$ and $c=10.6036(2) \AA$. This corresponds to an increase of the unit cell by $3.2 \%(V=905.79(3)$ $\left.\AA^{3}\right)$ relative to the pristine NVPF phase $\left(V=878.05(3) \AA^{3}\right)$, which is consistent with the uptake of extra sodium upon reduction. a

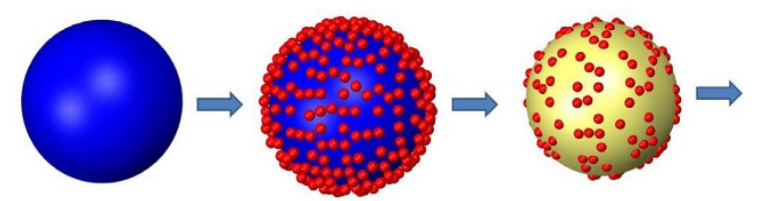

b
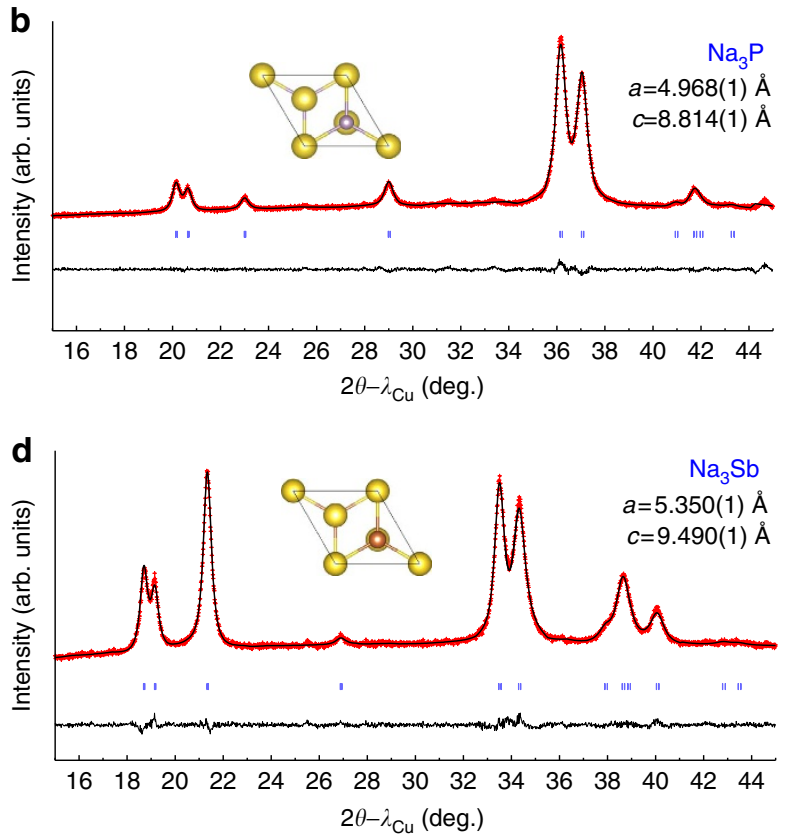

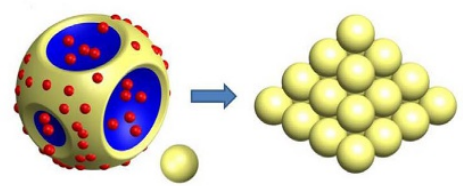

C
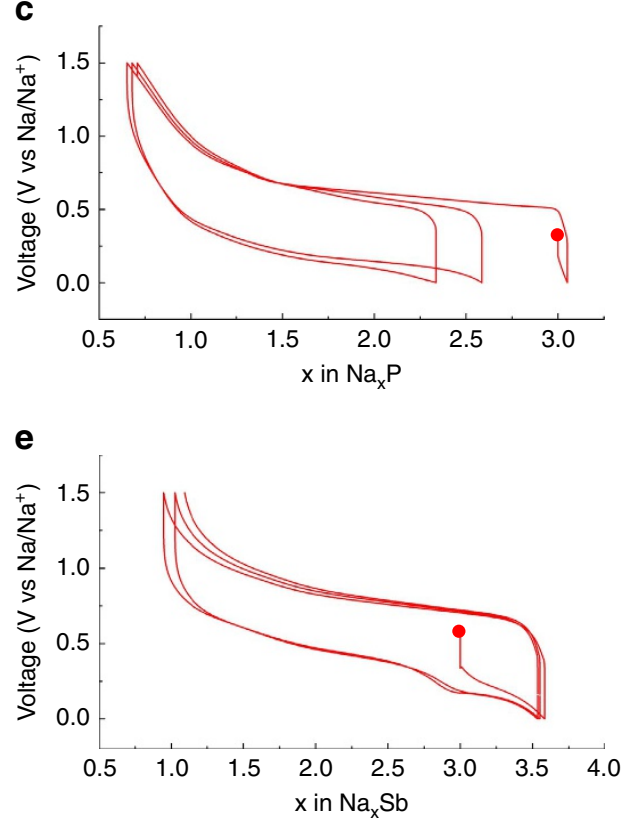

Figure 1 | Synthesis of $\mathbf{N a - b a s e d ~ a l l o y s . ~ ( a ) ~ S c h e m a t i c ~ d i a g r a m ~ s h o w i n g ~ t h e ~ b a l l ~ m i l l i n g ~ p r o c e s s ~ e x e m p l i f i e d ~ f o r ~ t h e ~ f o r m a t i o n ~ o f ~} \mathrm{Na}_{x} \mathrm{M}$ alloys (yellow) by reacting $\mathrm{Na}$ (blue) with metal $\mathrm{M}\left(\mathrm{M}=\mathrm{P}\right.$ or $\mathrm{Sb}$ ) (red). In $\mathbf{b}, \mathbf{c}$ and $\mathbf{d}, \mathbf{e}$, the Rietveld refined $\mathrm{X}$-ray powder patterns of $\mathrm{Na}_{3} \mathrm{P}$ and $\mathrm{Na}_{3} \mathrm{Sb}$ powders are respectively shown together with their corresponding electrochemical voltage-profile in Na-half cells. 
Refinement of the synchrotron XRD pattern (Fig. 3c) of the obtained $\mathrm{Na}_{4} \mathrm{~V}_{2}\left(\mathrm{PO}_{4}\right)_{2} \mathrm{~F}_{3}$ was undertaken based on the structural model reported for pristine NVPF by Bianchini et al. ${ }^{26}$ The $\mathrm{VO}_{6}$ octahedra and $\mathrm{PO}_{4}$ tetrahedra arrangement of NVPF is kept, and the best agreement between the observed and calculated patterns was found for the $\mathrm{Na}$ positions as listed in Supplementary Tables 1 and 2 and Supplementary Note 1. The Na environments are shown in Fig. 3e. The three distinct $\mathrm{Na}$ sites are all seven-fold coordinated with four oxygen and three fluorine atoms, which is analogous to the coordination of Nal in NVPF (Fig. 3g). The structural analysis fully confirms the chemical composition $\left(\mathrm{Na}_{4} \mathrm{~V}_{2}\left(\mathrm{PO}_{4}\right)_{2} \mathrm{~F}_{3}\right)$ and indicates that there is apparently no further space for $\mathrm{Na}$ insertion. Lastly, the synchrotron XRD patterns of the sample prepared by ball milling NVPF with $\mathrm{Na}$ for 30 min can be perfectly refined with a two phases model: NVPF and $\mathrm{Na}_{4} \mathrm{~V}_{2}\left(\mathrm{PO}_{4}\right)_{2} \mathrm{~F}_{3}$, as shown in Fig. $3 \mathrm{~b}$.

The occurrence of $\mathrm{Na}_{4} \mathrm{~V}_{2}\left(\mathrm{PO}_{4}\right)_{2} \mathrm{~F}_{3}$ comes as a total surprise, as no extra capacity has ever been reported for NVPF at low potential. It is however worth noting that the reversible insertion of $1 \mathrm{Na}^{+}$at $0.3 \mathrm{~V}$ was just recently reported for $\mathrm{Na}_{3} \mathrm{~V}_{2}\left(\mathrm{PO}_{4}\right)_{3}$ (ref. 27). Knowing the existence of the two $\mathrm{Na}_{3} \mathrm{~V}_{2}\left(\mathrm{PO}_{4}\right)_{2} \mathrm{~F}_{3}$ and $\mathrm{Na}_{4} \mathrm{~V}_{2}\left(\mathrm{PO}_{4}\right)_{2} \mathrm{~F}_{3}$ end-member phases, we deliberately prepared composites of nominal compositions having different amounts of NVPF and $\mathrm{Na}_{4} \mathrm{~V}_{2}\left(\mathrm{PO}_{4}\right)_{2} \mathrm{~F}_{3}$ that will be denoted hereafter ' $\mathrm{Na}_{3+x} \mathrm{~V}_{2}\left(\mathrm{PO}_{4}\right)_{2} \mathrm{~F}_{3}$ '. Such as-prepared composites show similar electrochemical performance as NVPF, except $x$ more $\mathrm{Na}$ is removed during the first oxidation (Fig. 3h). They deliver a stable capacity of $\sim 110 \mathrm{mAhg}^{-1}$ when cycled between 4.4 and $3 \mathrm{~V}$.

In light of our finding on the $\mathrm{Na}_{4} \mathrm{~V}_{2}\left(\mathrm{PO}_{4}\right)_{2} \mathrm{~F}_{3}$ phase, we explored electrochemical intercalation in NVPF down to low voltages. In situ XRD measurements were conducted on a $\mathrm{Na} / \mathrm{NVPF}$ cell, with XRD patterns collected for every $90 \mathrm{~min}$. As the cell was being discharged at $0.15 \mathrm{C}$, we observed the progressive appearance of an additional set of peaks (Fig. 4a,b) corresponding to the $\mathrm{Na}_{4} \mathrm{~V}_{2}\left(\mathrm{PO}_{4}\right)_{2} \mathrm{~F}_{3}$ phase obtained by ball milling. They appear at the expense of the NVPF reflections, which barely change in position but decrease in intensity. By careful refinement of the XRD patterns, we quantified (Fig. 4c) the growing amounts of $\mathrm{Na}_{4} \mathrm{~V}_{2}\left(\mathrm{PO}_{4}\right)_{2} \mathrm{~F}_{3}$, promoted by continuously lowering the reduction voltage; $\mathrm{Na}_{4} \mathrm{~V}_{2}\left(\mathrm{PO}_{4}\right)_{2} \mathrm{~F}_{3}$ constitutes nearly $60 \%$ of the composite when the cell potential reaches $0 \mathrm{~V}$. This corresponds to a $x$ value of 0.6 (in ' $\mathrm{Na}_{3+x} \mathrm{~V}_{2}\left(\mathrm{PO}_{4}\right)_{2} \mathrm{~F}_{3}$ '), which cannot be determined accurately from coulometric titration because of side reactions (Supplementary Note 2 and Supplementary Figs 4 and 5). Turning to the charging process, a reverse trend is observed, with the recovery at $3.6 \mathrm{~V}$ of an XRD pattern similar to that of the pristine phase indicating the full reversibility of the Na-uptake-removal process (Fig. 4a). However, it is worth noting the drastic difference in the charge and discharge profiles, highlighted in the derivative plot (Supplementary Fig. 4a,b), which is indicative of a different reacting pathway. Moreover, we note the continuous growing of $\mathrm{Na}_{4} \mathrm{~V}_{2}\left(\mathrm{PO}_{4}\right)_{2} \mathrm{~F}_{3}$ when the cell is switched back to
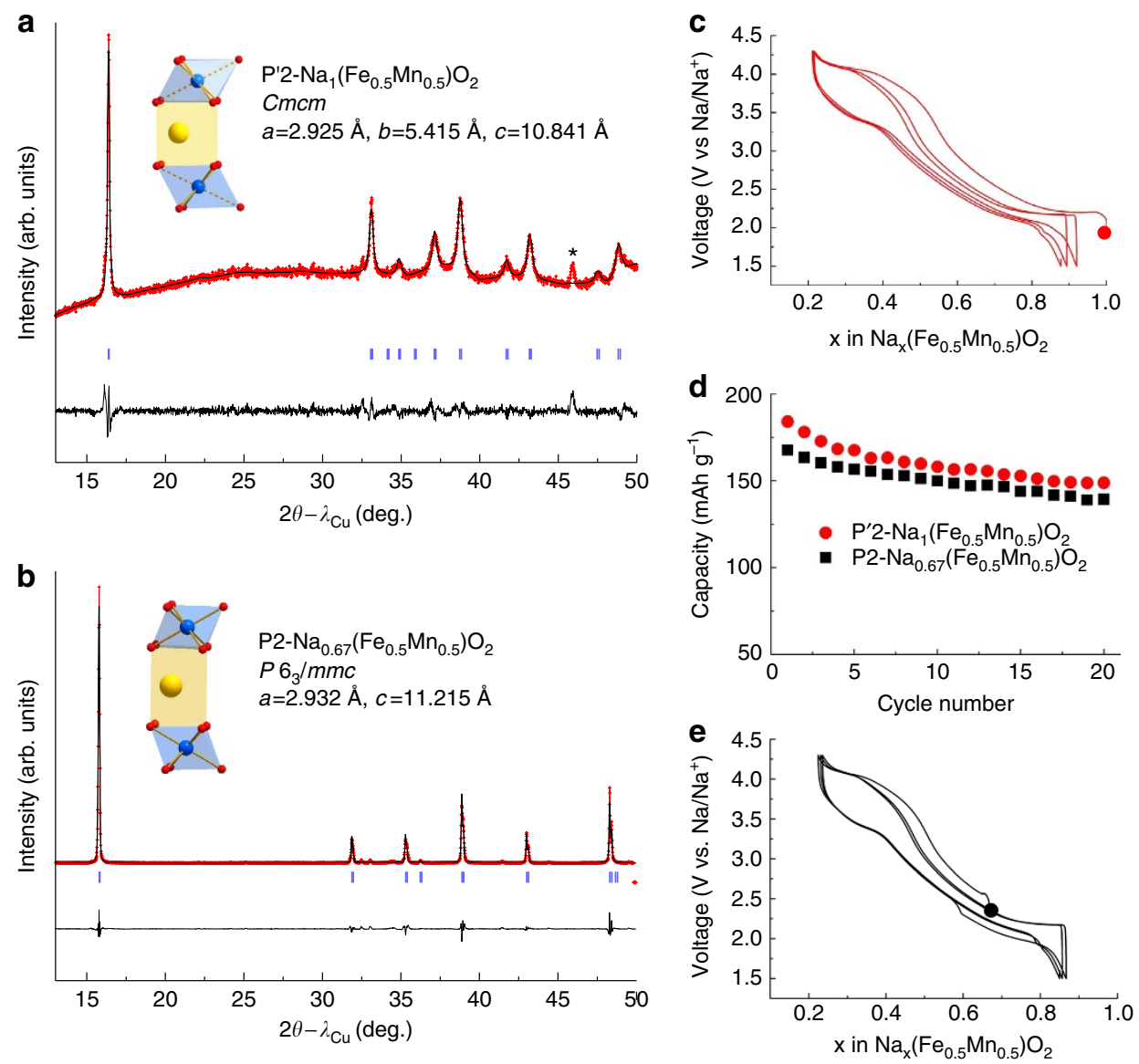

Figure 2 | Synthesis of the $\mathbf{P}^{\prime} \mathbf{2}$ phase by $\mathbf{N a}$ ball milling. XRD powder pattern profile matching and schematic representation of the structure of (a) $\mathrm{P}^{\prime} 2-\mathrm{Na}_{1}\left[\mathrm{Fe}_{0.5} \mathrm{Mn}_{0.5}\right] \mathrm{O}_{2}$ obtained using ball milling with $\mathrm{Na}$ and (b) pristine $\mathrm{P} 2-\mathrm{Na}_{0.67}\left[\mathrm{Fe}_{0.5} \mathrm{Mn}_{0.5}\right] \mathrm{O}_{2}$. The refined cell parameters are in agreement with reported ones for both $\mathrm{P} 2$ and $\mathrm{P}^{\prime} 2$ phases. The change of symmetry from P2 to P'2 accounts for the distortion of the $\mathrm{MnO}_{6}$ octahedral due to the Jahn-Teller effect of reduced $\mathrm{Mn}^{3+}$; voltage profiles of (c) $\mathrm{P}^{\prime} 2-\mathrm{Na}_{1}\left[\mathrm{Fe}_{0.5} \mathrm{Mn}_{0.5}\right] \mathrm{O}_{2}$, (e) $\mathrm{P} 2-\mathrm{Na}_{0.67}\left[\mathrm{Fe}_{0.5} \mathrm{Mn}_{0.5}\right] \mathrm{O}_{2}$ and their corresponding cycling performances in Na-half cells (d). The peak marked with an asterisk $\left.{ }^{*}\right)$ in $\mathbf{a}$ is attributed to Be window used to measure such a moisture sensitive sample. 

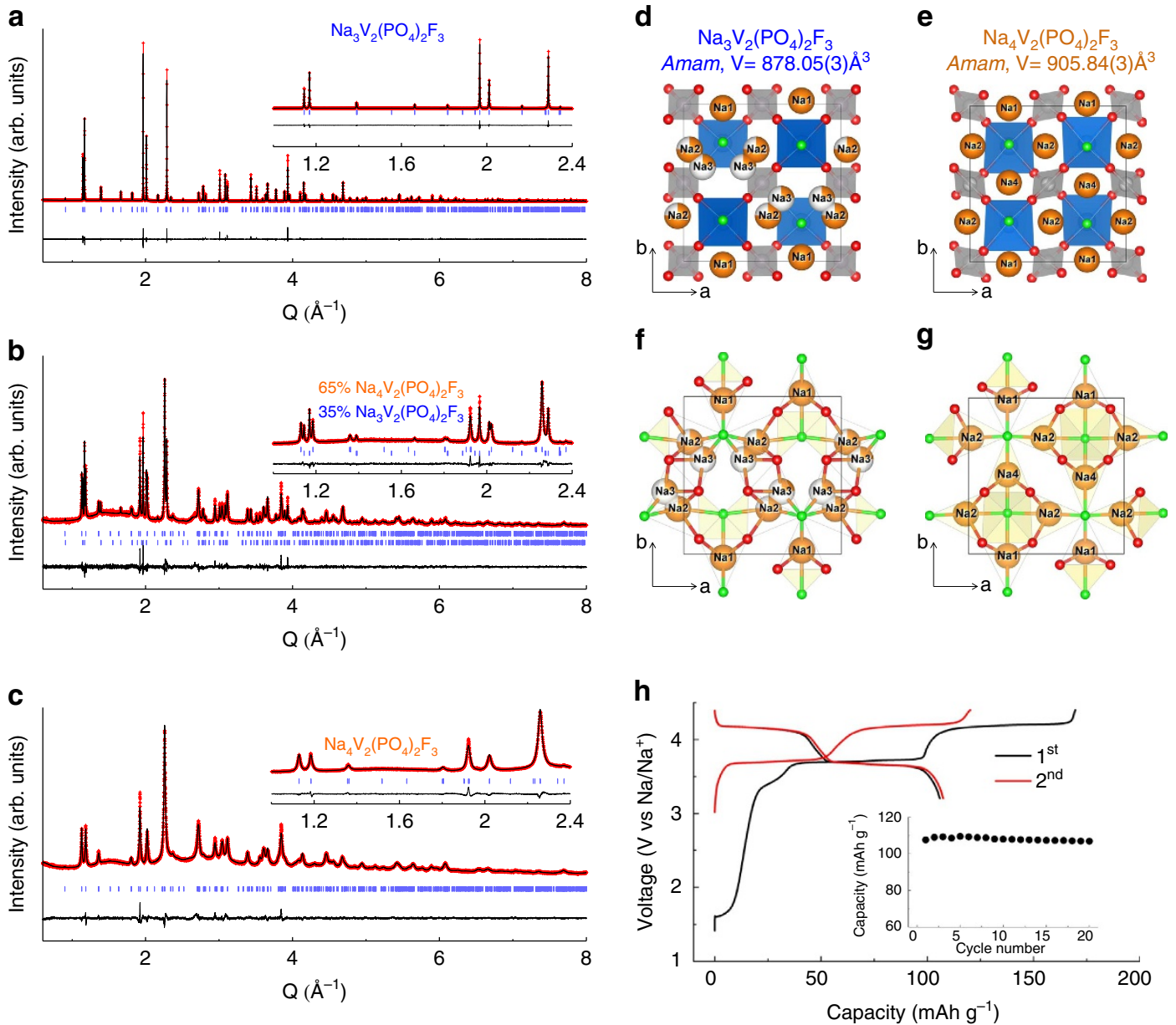

Figure 3 | Synthesis and electrochemistry of $\mathbf{N a}_{\mathbf{4}} \mathbf{V}_{\mathbf{2}}\left(\mathbf{P O}_{\mathbf{4}}\right)_{\mathbf{2}} \mathbf{F}_{\mathbf{3}}$ by $\mathbf{N a}$ reductive ball milling. Rietveld refinements of pristine $\mathrm{Na}_{3} \mathrm{~V}_{2}\left(\mathrm{PO}_{4}\right)_{2} \mathrm{~F}_{3}(\mathbf{a})$, a mixture of $\mathrm{Na}_{3} \mathrm{~V}_{2}\left(\mathrm{PO}_{4}\right)_{2} \mathrm{~F}_{3}$ and $\mathrm{Na}_{4} \mathrm{~V}_{2}\left(\mathrm{PO}_{4}\right)_{2} \mathrm{~F}_{3}(\mathbf{b})$ and pure $\mathrm{Na}_{4} \mathrm{~V}_{2}\left(\mathrm{PO}_{4}\right)_{2} \mathrm{~F}_{3}(\mathbf{c})$. The red crosses, black continuous line and bottom grey line represent the observed, calculated and difference patterns, respectively. Vertical blue tick bars mark the Bragg reflections arising from the Amam space group. Patterns are given in Q-space for allowing a direct comparison. Structure of $\mathrm{Na}_{3} \mathrm{~V}_{2}\left(\mathrm{PO}_{4}\right)_{2} \mathrm{~F}_{3}(\mathbf{d}, \mathbf{f})$ and of $\mathrm{Na}_{4} \mathrm{~V}_{2}\left(\mathrm{PO}_{4}\right)_{2} \mathrm{~F}_{3}(\mathbf{e}, \mathbf{g})$ as deduced from the refinement of the synchrotron patterns. The $\mathrm{Na}$ environment of $\mathrm{Na}_{3} \mathrm{~V}_{2}\left(\mathrm{PO}_{4}\right)_{2} \mathrm{~F}_{3}$ and $\mathrm{Na}_{4} \mathrm{~V}_{2}\left(\mathrm{PO}_{4}\right)_{2} \mathrm{~F}_{3}$ is respectively highlighted in $(\mathbf{f}, \mathbf{g})$. $\mathrm{VO}_{4} \mathrm{~F}_{2}$ octahedral and $\mathrm{PO}_{4}$ tetrahedral are coloured in blue and grey, respectively. $\mathrm{Na}$ and $\mathrm{F}$ atoms are shown as orange and green balls, respectively. Vacancies on the $\mathrm{Na} 1$ and $\mathrm{Na} 2$ sites on $\mathrm{Na}_{3} \mathrm{~V}_{2}\left(\mathrm{PO}_{4}\right)_{2} \mathrm{~F}_{3}$ are coloured in white. The electrochemical behaviour of composite ' $\mathrm{Na}_{3.5} \mathrm{~V}_{2}\left(\mathrm{PO}_{4}\right)_{2} \mathrm{~F}_{3}$ ' (that is, with equal amounts of $\mathrm{Na}_{3} \mathrm{~V}_{2}\left(\mathrm{PO}_{4}\right)_{2} \mathrm{~F}_{3}$ and $\left.\mathrm{Na}_{4} \mathrm{~V}_{2}\left(\mathrm{PO}_{4}\right)_{2} \mathrm{~F}_{3}\right)$ in Na-half cell is shown in $\mathbf{h}$.

oxidation, further implying a complex Na-uptake-removal process. We believe this partial reduction to be nested in kinetics blockages that are most likely due to the growth of a thick insulating SEI layer due to copious electrolyte decomposition and/or the formation of peculiar self-limiting core-shell-like ' $\mathrm{Na}_{3+x} \mathrm{~V}_{2}\left(\mathrm{PO}_{4}\right)_{2} \mathrm{~F}_{3}$ ' particles upon reduction. Besides, attempts to modify the SEI with the use of fluoroethylene carbonate (FEC) did not result in subsequent changes in increasing the amount of the $\mathrm{Na}_{4} \mathrm{~V}_{2}\left(\mathrm{PO}_{4}\right)_{2} \mathrm{~F}_{3}$ phase (Supplementary Note 2). In comparison, there are two specific aspects that facilitate the production of pure $\mathrm{Na}_{4} \mathrm{~V}_{2}\left(\mathrm{PO}_{4}\right)_{2} \mathrm{~F}_{3}$ in the case of ball milling synthesis. They enlist the absence of SEI formation because of the lack of electrolyte, and the continuous formation of highly reacting fresh surfaces due to repeated fracturing.

These examples highlight the benefits of ball milling-driven Na-reduction reactions, which are free of the complexities associated with handling reactive solutions or using mild temperature processing to prepare fully reduced materials. The synthesized $\mathrm{P}^{\prime} 2-\mathrm{Na}_{1}\left[\mathrm{Fe}_{0.5} \mathrm{Mn}_{0.5}\right] \mathrm{O}_{2}$ and ' $\mathrm{Na}_{3+x} \mathrm{~V}_{2}\left(\mathrm{PO}_{4}\right)_{2} \mathrm{~F}_{3}$ ' show similar cyclic and rate performance (Supplementary Fig. 6) as the pristine $\mathrm{P} 2-\mathrm{Na}_{0.67}\left[\mathrm{Fe}_{0.5} \mathrm{Mn}_{0.5}\right] \mathrm{O}_{2}$ and $\mathrm{NVPF}$, respectively, demonstrating that the short ball milling time does not bring any detrimental effect to its electrochemical performance. Such reactions, leading to the transformation of $\mathrm{P} 2$ to $\mathrm{P}^{\prime} 2$, or NVPF to $\mathrm{Na}_{4} \mathrm{~V}_{2}\left(\mathrm{PO}_{4}\right)_{2} \mathrm{~F}_{3}$, are topotatic since the host structural frameworks are unaltered, and can simply be viewed as insertion reactions. Thus, the reactivity is simply dictated by the redox potential associated with the insertion of $\mathrm{Na}$ in various compounds. As shown in the electrochemical energy scale schematic representation in Fig. 5b, although $\mathrm{Na}_{3} \mathrm{P}$ is a milder reducing reagent than $\mathrm{Na}\left(0.5 \mathrm{~V}\right.$ versus $\left.\mathrm{Na}^{+} / \mathrm{Na}^{0}\right)$, it is also expected to reduce $\mathrm{P} 2$ and NVPF. To test this point, as we have done for $\mathrm{Na}$, a survey of various ball milling times together with various amounts of $\mathrm{Na}_{3} \mathrm{P}$ were conducted and the obtained composites were periodically checked for phase purity. We find the possibility to successfully prepare the $\mathrm{Na}_{4} \mathrm{~V}_{2}\left(\mathrm{PO}_{4}\right)_{2} \mathrm{~F}_{3}$ phase (Fig. 5a) as well as the $\mathrm{P}^{\prime} 2$ phase (Fig. 5c) by ball milling powdered mixtures of NVPF and P2 with 1 and 0.2 molar amounts of $\mathrm{Na}_{3} \mathrm{P}$, respectively. The reaction between $\mathrm{Na}_{3} \mathrm{P}$ and NVPF could be classified as chemical sodiation. The successful sodiation of $\mathrm{NVPF}$ by $\mathrm{Na}_{3} \mathrm{P}$ suggests that the reduction potential of NVPF should be higher than the potential for $\mathrm{Na}_{3} \mathrm{P}$ oxidation, that is, $\sim 0.5 \mathrm{~V}$. The advantage of $\mathrm{Na}_{3} \mathrm{P}$ as compared with $\mathrm{Na}$ metal is the fact it is a powder, although there is a compromise for 

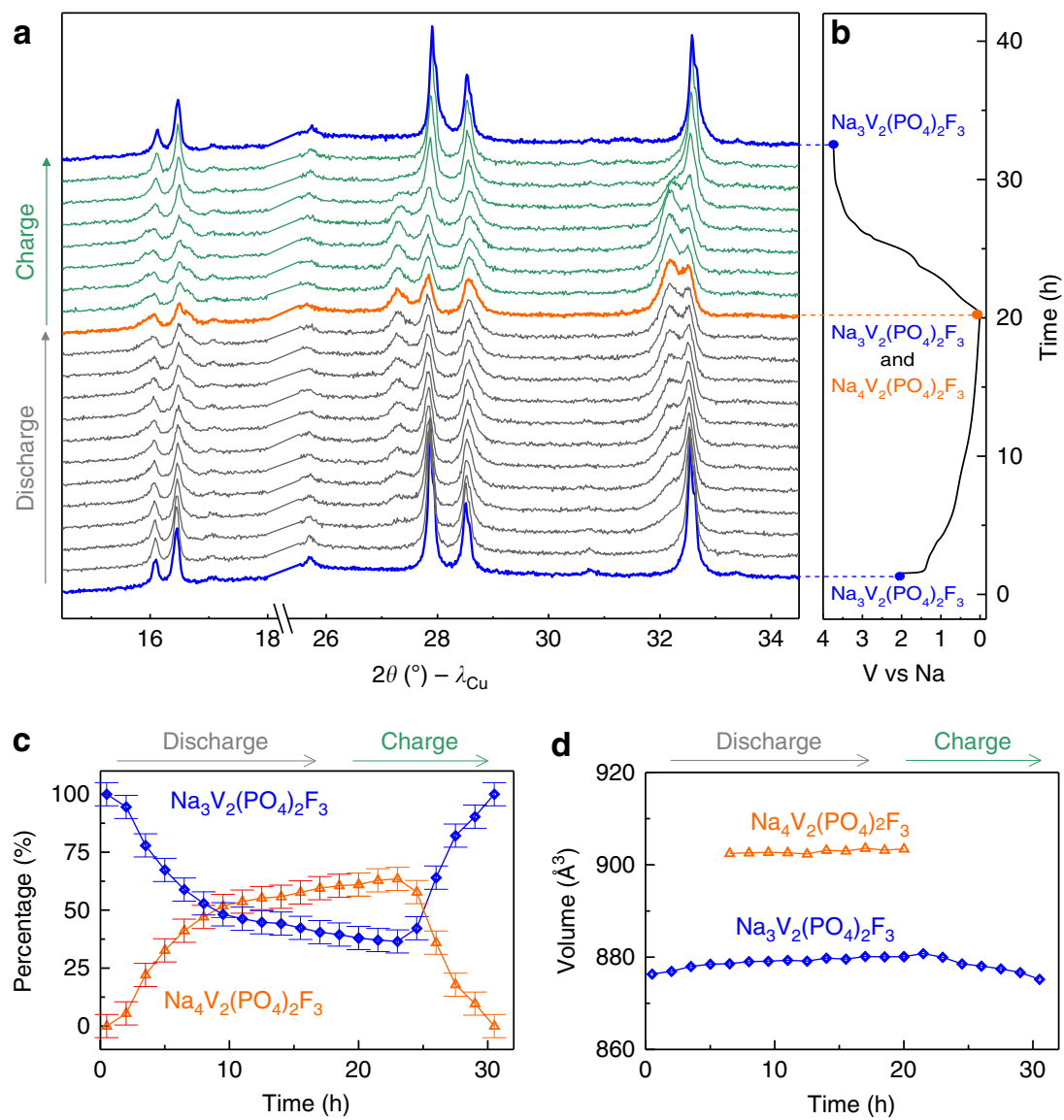

Figure 4 | In situ XRD patterns collected for a $\mathbf{N a}_{\mathbf{3}} \mathbf{V}_{\mathbf{2}}\left(\mathbf{P O}_{\mathbf{4}}\right)_{\mathbf{2}} \mathbf{F}_{\mathbf{3}} / \mathrm{Na}$ cell. XRD patterns $(\mathbf{a})$ and the corresponding electrochemical curve $(\mathbf{b})$ is shown. The percentage of each phase and their unit cell volumes are shown in $\mathbf{c}, \mathbf{d}$, respectively. Error bars represent standard deviation obtained from the Rietveld refinement. Note that the $\mathrm{Na}_{4} \mathrm{~V}_{2}\left(\mathrm{PO}_{4}\right)_{2} \mathrm{~F}_{3}$ phase mainly forms at the beginning of the process (within the 1.4-0.8 $\mathrm{V}$ domain) and then the Na-uptake appears self-limiting for reasons explained with the text. For time $>20 \mathrm{~h}$ the amount of $\mathrm{Na}_{4} \mathrm{~V}_{2}\left(\mathrm{PO}_{4}\right)_{2} \mathrm{~F}_{3}$ within the accuracy of the measurements still increases, while the cell is already in its oxidation mode.

a

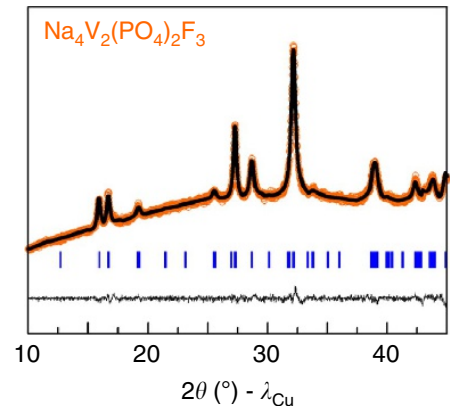

b

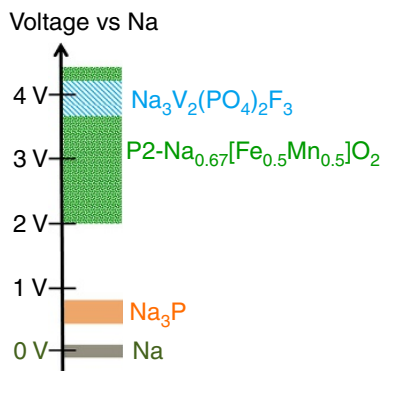

C

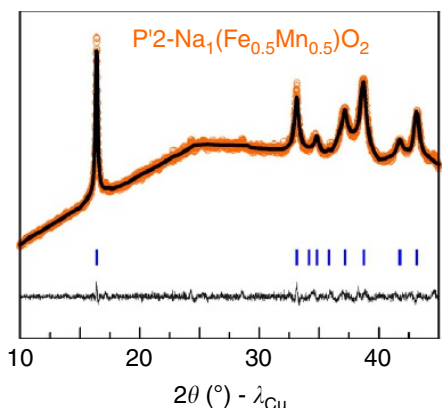

Figure $\mathbf{5}$ | Synthesis of $\mathbf{N a}_{\mathbf{4}} \mathbf{V}_{\mathbf{2}}\left(\mathbf{P O}_{\mathbf{4}}\right)_{\mathbf{2}} \mathbf{F}_{\mathbf{3}}$ and $\mathbf{P} / \mathbf{2}$ phase by $\mathbf{N a}_{\mathbf{3}} \mathbf{P}$ ball milling. The XRD Rietveld refinement of $(\mathbf{a}) \mathrm{Na}_{4} \mathrm{~V}_{2}\left(\mathrm{PO}_{4}\right)_{2} \mathrm{~F}_{3}$ and the profile matching of (c) $\mathrm{P}^{\prime} 2-\mathrm{Na}_{1}\left[\mathrm{Fe}_{0.5} \mathrm{Mn}_{0.5}\right] \mathrm{O}_{2}$ phase obtained by ball milling using $\mathrm{Na}_{3} \mathrm{P}$ as a reducing reagent are shown together with in the middle an electrochemical scale ranking the various used compounds in terms of redox potentials (b). In $\mathbf{a}, \mathbf{c}$ the orange open circles, black continuous line and bottom grey line represent the observed, calculated, and difference patterns, respectively. Vertical blue tick bars mark the Bragg reflections.

this convenience with the requirements of excess amounts of $\mathrm{Na}_{3} \mathrm{P}$ and longer ball milling time.

Na-enriched phases for highly efficient $\mathrm{Na}$-ion batteries. The successful preparation of Na-rich $\mathrm{Na}_{4} \mathrm{~V}_{2}\left(\mathrm{PO}_{4}\right)_{2} \mathrm{~F}_{3}$ or composites with known amounts of NVPF and $\mathrm{Na}_{4} \mathrm{~V}_{2}\left(\mathrm{PO}_{4}\right)_{2} \mathrm{~F}_{3}$ enables control over the extra $\mathrm{Na}$ content by playing with ball milling times, and is of great importance for enhancing the performances of $\mathrm{C} / \mathrm{NVPF} \mathrm{Na}$-ion cells. This situation closely mirrors the use of $\mathrm{Li}_{1+}{ }_{x} \mathrm{Mn}_{2} \mathrm{O}_{4}$ as a Li source in C/LiMn $\mathrm{O}_{4}$ Li-ion cells ${ }^{12}$, since the extra Na${ }^{+}$ions present in NVPF can be removed at low potential without an added weight penalty with exception to the weight of the $x$ added Na. As a proof of concept, we assembled various electrochemical cells having carbon as the negative electrode and either the pristine NVPF phase or the ' $\mathrm{Na}_{3}{ }_{x} \mathrm{~V}_{2}\left(\mathrm{PO}_{4}\right)_{2} \mathrm{~F}_{3}$ ' composites as the positive electrode. For conciseness, we focus 

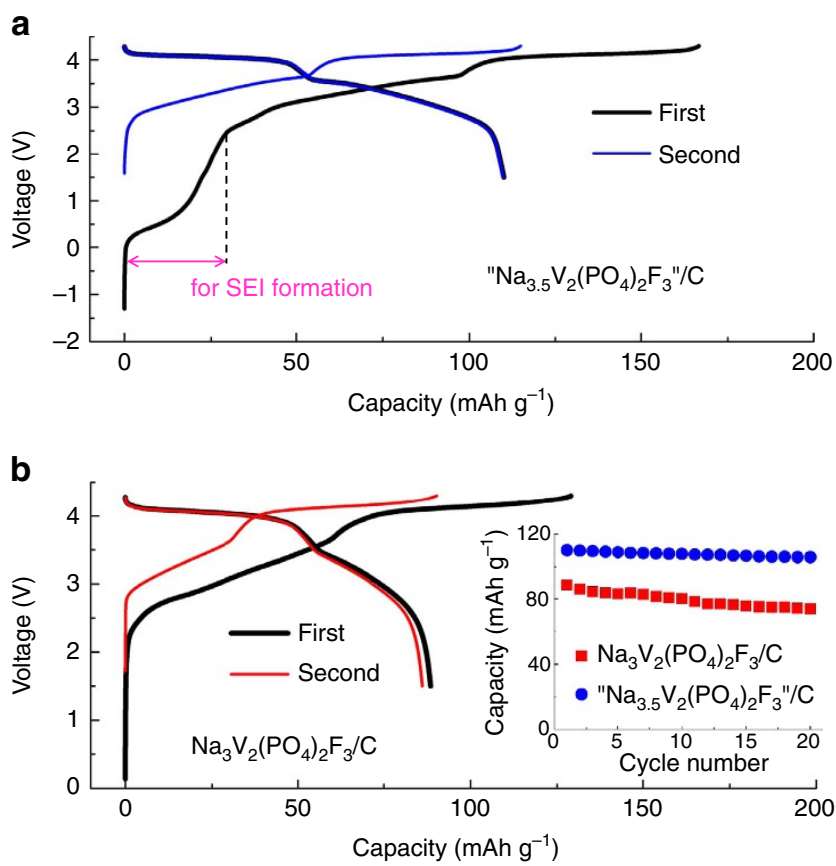

Figure 6 | Performances of $\mathrm{C} /{ }^{\prime} \mathrm{Na}_{3}+{ }_{x} \mathbf{V}_{2}\left(\mathrm{PO}_{4}\right)_{2} \mathbf{F}_{3}$ ' Na-ion cells. The voltage-composition profiles are reported for two first cycles for cell $\mathrm{Cl}$ using $\mathrm{Na}_{3} \mathrm{~V}_{2}\left(\mathrm{PO}_{4}\right)_{2} \mathrm{~F}_{3}$ (b) and cell $\mathrm{C} 2$ using ' $\mathrm{Na}_{3.5} \mathrm{~V}_{2}\left(\mathrm{PO}_{4}\right)_{2} \mathrm{~F}_{3}$ ' (a).

The weight ratio of cathode to anode is 2.7 and 1.9 for $\mathrm{C} 1$ and $\mathrm{C} 2$ cell, respectively. The cells were cycled at a $0.2 \mathrm{C}$ rate ( $\mathrm{C}$ rate being defined as the extraction of $2 \mathrm{Na}$ from NVPF). For both cells a $1 \mathrm{M} \mathrm{NaClO}_{4}$ in $\mathrm{EC} / \mathrm{DMC}$ ( $50 / 50$ by volume) electrolyte was used. The capacity is calculated based on the weight of positive materials. Inset in (b) shows the capacity retention in the first 20 cycles.

here only on the performance for the optimum $x$ value. This value was estimated to be equal to 0.5 for compensating the $\sim 25 \%$ irreversible capacity related to the SEI. Details about the balancing of cathode and anode are described in Supplementary Fig. 7 and Supplementary Note 3. Figure 6 shows the electrochemical performances of cells $\mathrm{C} 1$ and $\mathrm{C} 2$, having pristine NVPF and composite ' $\mathrm{Na}_{3.5} \mathrm{~V}_{2}\left(\mathrm{PO}_{4}\right)_{2} \mathrm{~F}_{3}$ ' as positive electrodes, respectively. The cells were tested electrochemically between 1.5 and $4.3 \mathrm{~V}$. The voltage trace for $\mathrm{C} 1$ mirrors reports in the literature for similar cells with a charging capacity of $129 \mathrm{mAhg}^{-1}$ and a discharge capacity of $89 \mathrm{mAhg}^{-1}$, which remains stable upon cycling. Providing sacrificial $\mathrm{Na}$ in the form of Na-rich NVPF (C2) strongly modifies the voltage profile: an initial capacity near $0.5 \mathrm{~V}$ corresponds to the removal of $\mathrm{Na}$ from ' $\mathrm{Na}_{3.5} \mathrm{~V}_{2}\left(\mathrm{PO}_{4}\right)_{2} \mathrm{~F}_{3}$ ' to compensate for the SEI formation at the negative electrode; afterwards the potential rises, associated with removal of $\mathrm{Na}$ from NVPF. The C2 cell exhibits an overall charging capacity of $167 \mathrm{mAhg}^{-1}$ and a discharge capacity of $110 \mathrm{mAh} \mathrm{g}^{-1}$, which is a $24 \%$ enhancement compared with cell $\mathrm{C} 1$. This corresponds to an overall $10 \%$ increase in energy density as described in Supplementary Note 4. Lastly, there is no evidence to suggest that use of the Na-rich phase jeopardizes the cycle life, with the capacity remaining nearly constant over 20 cycles (the maximum we have tried). Needless to say that further optimization of cell balancing via the use of three electrodes is being pursued to fine tune the proper value of $x$ for achieving optimum performance.

We next implemented a similar approach in the optimization of C/P2-type $\mathrm{Na}_{0.67}\left[\mathrm{Fe}_{0.5} \mathrm{Mn}_{0.5}\right] \mathrm{O}_{2} \mathrm{Na}$-ion systems. In contrast to $\mathrm{NVPF}$, the positive $\mathrm{P}^{\prime} 2-\mathrm{Na}_{1}\left[\mathrm{Fe}_{0.5} \mathrm{Mn}_{0.5}\right] \mathrm{O}_{2}$ phase cannot act as an extra source of $\mathrm{Na}$ since Na-rich $\mathrm{Na}_{1+x}\left[\mathrm{Fe}_{0.5} \mathrm{Mn}_{0.5}\right] \mathrm{O}_{2}$ does not exist. This is easily overcome by first preparing the $\mathrm{P}^{\prime} 2-\mathrm{Na}_{1}\left[\mathrm{Fe}_{0.5} \mathrm{Mn}_{0.5}\right] \mathrm{O}_{2}$ phase by Na-ball milling and then homogeneously mixing the $\mathrm{P}^{\prime} 2$ phase with the proper amount of $\mathrm{Na}_{3} \mathrm{P}$ to compensate for the carbon irreversible capacity. We here use extra $\mathrm{Na}_{3} \mathrm{P}$, rather than $\mathrm{Na}$ metal, as it is easily added as powders to positive electrode materials to make homogeneous composite electrodes. Upon charging the cell, the added $\mathrm{Na}_{3} \mathrm{P}$ will oxidize to compensate for the $\mathrm{Na}$ consumed in SEI formation during the first cycle. This leaves behind elemental phosphorous, which remains as an electrochemical spectator within the cell upon subsequent cycles (Supplementary Fig. 8), but which also has the capability to act as a safety buffer by reinserting $\mathrm{Na}$ at a constant voltage in case of cell over-discharge.

A series of full $\mathrm{Na}$-ion cells were assembled using carbon negative electrodes and composite positive electrodes made of $\mathrm{P} 2-\mathrm{Na}_{0.67}\left[\mathrm{Fe}_{0.5} \mathrm{Mn}_{0.5}\right] \mathrm{O}_{2}$ (cell D1), $\mathrm{P}^{\prime} 2-\mathrm{Na}_{1}\left[\mathrm{Fe}_{0.5} \mathrm{Mn}_{0.5}\right] \mathrm{O}_{2}$ (cell D2) and $\mathrm{P}^{\prime} 2-\mathrm{Na}_{1}\left[\mathrm{Fe}_{0.5} \mathrm{Mn}_{0.5}\right] \mathrm{O}_{2}+10$ wt.\% $\mathrm{Na}_{3} \mathrm{P}$ (cell D3). The corresponding voltage profiles for the cells, collected upon cycling between 0 and $4.3 \mathrm{~V}$ at a current rate of $0.1 \mathrm{C}$, are shown in Fig. $7 \mathrm{a}-\mathrm{c}$. The D1 cell shows a charge capacity of $112 \mathrm{mAh} \mathrm{g}^{-1}$ and a discharge capacity of only $71 \mathrm{mAh}^{-1}$ that is maintained upon subsequent cycling. These capacities are considerably lower than those obtained for $\mathrm{Na} / \mathrm{Na}_{0.67}\left[\mathrm{Fe}_{0.5} \mathrm{Mn}_{0.5}\right] \mathrm{O}_{2}$ half cells $\left(168 \mathrm{mAhg}^{-1}\right)$, due to the replacement of the $\mathrm{Na}$ anode by carbon, and hence the absence of a $\mathrm{Na}$ source to enable formation of the $\mathrm{P}^{\prime} 2$ phase and to compensate for losses to the SEI at the carbon electrode. In contrast, the D2 and D3 cells show charge capacities of 185 and $247 \mathrm{mAhg}^{-1}$, respectively, with corresponding discharge capacities of 128 and $155 \mathrm{mAhg}^{-1}$ that stabilized to 110 and $131 \mathrm{mAh} \mathrm{g}^{-1}$ after 20 cycles (Fig. $7 \mathrm{~d}$ ), the maximum we have tried so far. Note that cell D3, as opposed to cell D2, presents an extra voltage feature below $1 \mathrm{~V}$ in the first charge. The feature mirrors the voltage charge profile of a $\mathrm{Na}_{3} \mathrm{P} / \mathrm{C}$ cell (Fig. 7e), which nicely demonstrates the way $\mathrm{Na}_{3} \mathrm{P}$ works as a sacrificial $\mathrm{Na}$ source in a full $\mathrm{Na}$-ion cell. Owing to its $0.5 \mathrm{~V}$ redox potential versus $\mathrm{Na}^{+} / \mathrm{Na}^{0}, \mathrm{Na}_{3} \mathrm{P}$ initially clamps the positive electrode voltage at a lower potential than that of the negative electrode-carbon starts to uptake $\mathrm{Na}^{+}$at solely $1.5 \mathrm{~V}$ versus $\mathrm{Na}^{+} / \mathrm{Na}$, thus resulting in a negative output voltage of the cell to start with. Once the cell is charged, $\mathrm{Na}^{+}$ions are released from $\mathrm{Na}_{3} \mathrm{P}$ to compensate for the irreversible SEI formation on carbon with the cell voltage climbing to $1 \mathrm{~V}$; afterwards $\mathrm{Na}^{+}$is released from the $\mathrm{P}^{\prime} 2$ part of the positive electrode so that the voltage profiles of both cells become nearly identical. Application wise the observed increase in reversible capacities from 71 to 128 and $155 \mathrm{mAh} \mathrm{g}^{-1}$ for the D1, D2, and D3 cells, respectively, which occurs without any sacrifice to the capacity retention behaviour upon cycling (Fig. 7d), clearly demonstrates the benefits of pre-producing the $\mathrm{P}^{\prime} 2$ phase and incorporating $\mathrm{Na}_{3} \mathrm{P}$ as a $\mathrm{Na}$ reservoir. Such capacity improvements increase the energy density by $30 \%$ between C/P2- $\mathrm{Na}_{0.67}\left[\mathrm{Fe}_{0.5} \mathrm{Mn}_{0.5}\right] \mathrm{O}_{2}$ and $\mathrm{C} / \mathrm{P}^{\prime} 2-\mathrm{Na}_{1}\left[\mathrm{Fe}_{0.5} \mathrm{Mn}_{0.5}\right] \mathrm{O}_{2} \mathrm{Na}$-ion cells, and by an additional of $7 \%$ using $\mathrm{P}^{\prime} 2-\mathrm{Na}_{1}\left[\mathrm{Fe}_{0.5} \mathrm{Mn}_{0.5}\right] \mathrm{O}_{2} / \mathrm{Na}_{3} \mathrm{P}$ composites rather than solely $\mathrm{P}^{\prime} 2-\mathrm{Na}_{1}\left[\mathrm{Fe}_{0.5} \mathrm{Mn}_{0.5}\right] \mathrm{O}_{2}$ powders as positive electrodes (Supplementary Note 4).

\section{Discussion}

We have reported the preparation of Na-based alloys $\left(\mathrm{Na}_{3} \mathrm{Sb}\right.$, $\mathrm{Na}_{3} \mathrm{P}$ and so on) via an approach that relies on the ball milling of $\mathrm{Na}$ metal and have demonstrated that such an approach, using either $\mathrm{Na}$ or $\mathrm{Na}_{3} \mathrm{P}$ as reducing agents, can equally be used to easily prepare $\mathrm{P}^{\prime} 2-\mathrm{Na}_{1}\left[\mathrm{Fe}_{0.5} \mathrm{Mn}_{0.5}\right] \mathrm{O}_{2}$ layered oxide insertion compound, and to produce ' $\mathrm{Na}_{3+x} \mathrm{~V}_{2}\left(\mathrm{PO}_{4}\right)_{2} \mathrm{~F}_{3}$ ' composites with the $x=1$ composition being a single phase never reported so far. Such findings provide new insights for combating the irreversible capacity of NIBs, thereby significantly enhancing their 
a

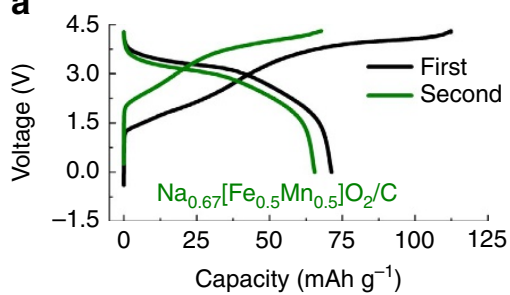

b

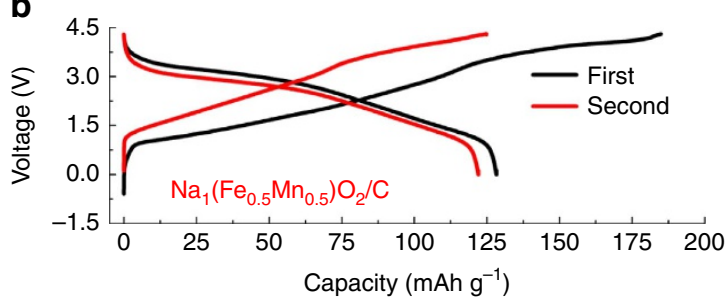

C

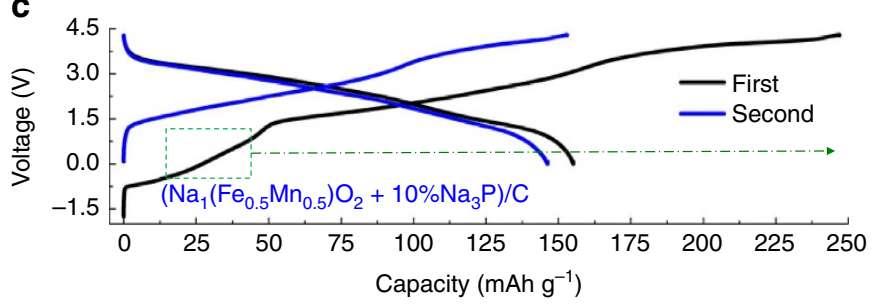

d

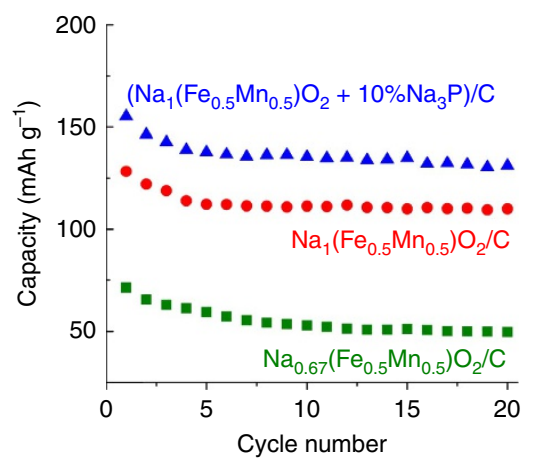

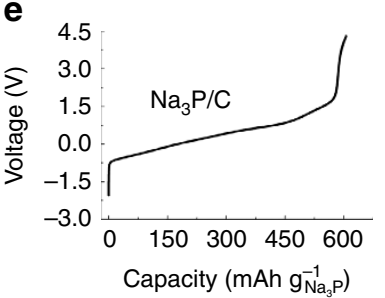

Figure 7 | Performances of $\mathbf{C} / \mathbf{P 2}-\mathbf{N a}_{\mathbf{0 . 6}}\left[\mathrm{Fe}_{\mathbf{0 . 5}} \mathbf{M n}_{\mathbf{0 . 5}}\right]_{\mathbf{2}} \mathbf{~ N a - i o n}$ cells. The voltage-composition profiles are reported for the two first cycles for cells using (a) as-made $\mathrm{P} 2-\mathrm{Na}_{0.67}\left[\mathrm{Fe}_{0.5} \mathrm{Mn}_{0.5}\right] \mathrm{O}_{2}$ (cell D1), (b) $\mathrm{P}^{\prime} 2-\mathrm{Na}_{1}\left[\mathrm{Fe}_{0.5} \mathrm{Mn}_{0.5}\right] \mathrm{O}_{2}$ made by $\mathrm{Na}$ ball milling (cell D2) and (c) for a $\mathrm{P}^{\prime} 2-\mathrm{Na}_{1}\left[\mathrm{Fe}_{0.5} \mathrm{Mn}_{0.5}\right] \mathrm{O}_{2} / \mathrm{Na}_{3} \mathrm{P}$ composite (cell D3) as positive electrode. The negative electrode is C. The weight ratio of positive to negative electrode is 2.6, 1.6 and 1.4 for D1, D2 and $\mathrm{D} 3$ cell, respectively. The cells were cycled at $0.1 \mathrm{C}$ rate. The capacity is based on the weight of positive materials, including $\mathrm{Na}_{3} \mathrm{P}$ for $\mathrm{D} 3$ cell. The capacity retention of D1, D2 and D3 cell is given (d), and e shows the first charge profile of a C/Na3 $\mathrm{P}$ cell. For all cells a $1 \mathrm{M} \mathrm{NaClO}{ }_{4}$ in $\mathrm{EC} / \mathrm{DMC}(50 / 50$ by volume) electrolyte was used.

performances. We demonstrate the feasibility of assembling full Na-ions cells showing marked enhancements in energy storage density (10-30\%) by using ' $\mathrm{Na}_{3}+{ }_{x} \mathrm{~V}_{2}\left(\mathrm{PO}_{4}\right)_{2} \mathrm{~F}_{3}$ ' and $\mathrm{P}^{\prime} 2-\mathrm{Na}_{1}\left[\mathrm{Fe}_{0.5} \mathrm{Mn}_{0.5}\right] \mathrm{O}_{2}$ as positive electrodes, respectively, with an extra $7 \%$ been achievable for the latter by adding proper amounts of $\mathrm{Na}_{3} \mathrm{P}$ sacrificial salt to $\mathrm{P}^{\prime} 2-\mathrm{Na}_{1}\left[\mathrm{Fe}_{0.5} \mathrm{Mn}_{0.5}\right] \mathrm{O}_{2}$ powders. The improvement in energy density associated to the addition of $\mathrm{Na}_{3} \mathrm{P}$ is here limited due to the low voltage of cathode at the end of the full discharge of the Na-ion cell. Since $\mathrm{N}$-methyl2-pyrrolidone (NMP) is used in today's electrode formulation technology we have checked the reactivity of $\mathrm{Na}_{3} \mathrm{P}$ towards NMP by directly immersing $\mathrm{Na}_{3} \mathrm{P} / \mathrm{C}$ composite in NMP overnight. No change has been observed in the $\mathrm{Na}_{3} \mathrm{P}$ crystallinity and its electrochemical activity was preserved with a capacity of $\sim 600 \mathrm{mAhg}^{-1}$ when oxidized to $4.3 \mathrm{~V}$. Nevertheless, an inherent difficulty, application wise, with such fully sodiated electrodes is their reactivity towards moisture, hence the need to design coating-grafting techniques to minimize such moisture sensitivity ${ }^{28}$ as it is being eagerly pursued in our group. Despite this practical pending issue, we anticipate that the here discussed means for enhancing the performances of NIBs will have strong implications towards their upcoming commercialization.

\section{Methods}

Synthesis of $\mathbf{N a}_{\mathbf{3}} \mathbf{P}$. Stoichiometric amounts of metallic sodium as bulk (Sigma) and red phosphorus (Alfa, 325 mesh) were filled into a hard steel ball-milled jar $\left(30 \mathrm{~cm}^{3}\right)$ of a Spex $8000 \mathrm{M}$ ball-miller in an Ar-filled glove box and equipped with seven hard steel balls each having a weight of $7 \mathrm{~g}$ and a diameter of $12 \mathrm{~mm}$. These solid materials were ball-milled for $2 \mathrm{~h}$ to obtain $\mathrm{Na}_{3} \mathrm{P}$ particles. The mass ratio of balls to $\mathrm{Na}_{3} \mathrm{P}$ was maintained at 35 . A similar protocol was used to prepare the reported $\mathrm{Na}_{3} \mathrm{Sb}$ powders.
Synthesis of $\mathbf{P}^{\prime} \mathbf{2}$ type $\mathbf{N a}_{\mathbf{1}}\left[\mathbf{F e}_{\mathbf{0 . 5}} \mathbf{M n}_{\mathbf{0 . 5}} \mathbf{O}_{\mathbf{2}}\right.$. P2 phase of $\mathrm{Na}_{0.67}\left[\mathrm{Fe}_{0.5} \mathrm{Mn}_{0.5}\right] \mathrm{O}_{2}$ was produced by solid-state reaction under $900{ }^{\circ} \mathrm{C}$ for $12 \mathrm{~h}$ in air ${ }^{10}$. It was ball milled with stoichiometric amount of $\mathrm{Na}$ to produce $\mathrm{Na}_{1}\left[\mathrm{Fe}_{0.5} \mathrm{Mn}_{0.5}\right] \mathrm{O}_{2}$ for durations from $20 \mathrm{~min}$ to $2 \mathrm{~h}$. Once the obtained powders were single phased, $20 \mathrm{wt} \%$ carbon $\mathrm{SP}$ was added and the mixture was ball milled for additional $10 \mathrm{~min}$ for making electrodes. Excess amounts of $\mathrm{Na}_{3} \mathrm{P}\left(0.2\right.$ mole $\mathrm{Na}_{3} \mathrm{P}$ per $\left.\mathrm{Na}_{0.67}\left[\mathrm{Fe}_{0.5} \mathrm{Mn}_{0.5}\right] \mathrm{O}_{2}\right)$ was also used to transfer $\mathrm{P} 2$ into $\mathrm{P}^{\prime} 2$ phase without noting any detrimental effect on the phase formation.

Synthesis of ' $\mathrm{Na}_{3}+{ }_{\mathbf{x}} \mathbf{V}_{\mathbf{2}}\left(\mathrm{PO}_{\mathbf{4}}\right)_{\mathbf{2}} \mathbf{F}_{\mathbf{3}}$ ' composites. Pure NVPF was obtained from CEA via a recently patented process. It was ball milled with increasing amounts of $\mathrm{Na}$ ranging from $0.5 \mathrm{Na}$ to $2 \mathrm{Na}$ per mole of NVPF and times ranging from $20 \mathrm{~min}$ to $3 \mathrm{~h}$. We find the formation of single phased materials for a stoichiometry of 2 $\mathrm{Na}$ and for ball milling time $>3 \mathrm{~h}$ (Supplementary Fig. 1). Such samples were shown to contain tiny amounts of remaining $\mathrm{Na}$ as deduced by DSC experiments (Supplementary Fig. 3). Equally, we could produce the fully sodiated

$\mathrm{Na}_{4} \mathrm{~V}_{2}\left(\mathrm{PO}_{4}\right)_{2} \mathrm{~F}_{3}$ phase by ball milling for $3 \mathrm{~h}$ of NVPF with $1 \mathrm{M}$ of $\mathrm{Na}_{3} \mathrm{P}$. Composites with adjusted values of $x$ in ' $\mathrm{Na}_{3}+x \mathrm{~V}_{2}\left(\mathrm{PO}_{4}\right)_{2} \mathrm{~F}_{3}$ ' to compensate for the carbon SEI negative electrode were made as above by properly adjusting amount of $\mathrm{Na}$ and ball milling time. Once the desired composite obtained, it was ball milled for 10 min with $20 \%$ additional carbon SP to make the electrode.

X-ray diffraction. XRD patterns were collected on a Bruker D8-Advance diffractometer equipped with $\mathrm{Cu} \mathrm{K} \alpha$ radiation source. Additional synchrotron XRD patterns were collected on powders put in sealed glass capillaries (diameter $0.7 \mathrm{~mm}$ ) either at the European Synchrotron Radiation Facility on ID22 with $\lambda=0.3543 \AA$ (Fig. 3a,c) or at 11BM-Argonne National Lab with $\lambda=0.4142 \AA$ (Fig. 3b). The in situ XRD patterns were recorded using electrochemical cells, assembled similarly to our Swagelok cell, but equipped with a beryllium window as current collector on the positive side. These cells were placed on the Bruker D8-Advance diffractometer ( $\mathrm{Cu} \mathrm{K} \alpha$ radiation) and connected to the VMP2 system. All patterns were analysed using the Rietveld method as implemented in the FullProf program ${ }^{29}$. Phase quantification was performed on the in situ patterns by applying a overall correction on the patterns to account for the absorption from the Be window. 
Electrochemical tests. Coin cells were used to study the electrochemical performances. $1 \mathrm{M} \mathrm{NaClO}_{4}$ solution in a mixture of EC/DMC in 1:1 ratio was used as electrolyte for the full cells with $\mathrm{C}$ as negative electrode. 5\% FEC was systematically added in half cells when $\mathrm{Na}$ metal was used as counter electrode. The only exception regards the cells made of NVPF as positive electrode that were initially discharged because of experimented interferences between the decomposition potential of FEC and the insertion reduction potential of $\mathrm{Na}$ into NVPF (Supplementary Figs 4 and 5). Two pieces of Whatman glass fibres soaked with the electrolyte were used as separator between the positive and negative electrode. The powders of active materials were mixed with $20 \%$ carbon SP using Spex $8000 \mathrm{M}$ mixer mill. A typical weight of $5 \mathrm{mg}$ of active electrode material was used per cell whatever Swagelok's or coin cells. The cells were galvanostatic charged/discharged with a VMP automatic cycling/data recording system (Biologic Co., Claix, France) using various ranges of scanning potential and $\mathrm{C}$ rates with $1 \mathrm{C}$ corresponding to the uptake or removal of $1 \mathrm{Na}^{+}$and $2 \mathrm{Na}^{+}$per formula unit in $1 \mathrm{~h}$ for $\mathrm{P} 2-\mathrm{Na}_{0.67}\left[\mathrm{Fe}_{0.5} \mathrm{Mn}_{0.5}\right] \mathrm{O}_{2}$ and NVPF, respectively. Note: While the present manuscript was under review, the $\mathrm{Na}_{4} \mathrm{~V}_{2}\left(\mathrm{PO}_{4}\right)_{2} \mathrm{~F}_{3}$ phase was predicted, but not synthesized, through computational calculation by Ceder's group $^{30}$.

\section{References}

1. Larcher, D. \& Tarascon, J. Towards greener and more sustainable batteries for electrical energy storage. Nat. Chem. 7, 19-29 (2014).

2. Kundu, D., Talaie, E., Duffort, V. \& Nazar, L. F. The emerging chemistry of sodium ion batteries for electrochemical energy storage. Angew. Chem. Int. Ed. Engl. 54, 3431-3448 (2015).

3. Palomares, V. et al. $\mathrm{Na}$-ion batteries, recent advances and present challenges to become low cost energy storage systems. Energy Environ. Sci. 5, 5884-5901 (2012).

4. Kim, Y., Ha, K.-H., Oh, S. M. \& Lee, K. T. High-capacity anode materials for sodium-ion batteries. Chem. Eur. J. 20, 11980-11992 (2014).

5. Stevens, D. A. \& Dahn, J. R. High capacity anode materials for rechargeable sodium-ion batteries. J. Electrochem. Soc. 147, 1271-1273 (2000)

6. Ponrouch, A. et al. Towards high energy density sodium ion batteries through electrolyte optimization. Energy Environ. Sci. 6, 2361-2369 (2013).

7. Park, Y. U. et al. A family of high-performance cathode materials for Na-ion batteries, $\mathrm{Na}_{3}\left(\mathrm{VO}_{1-x} \mathrm{PO}_{4}\right)_{2} \mathrm{~F}_{1+2}{ }_{x}(0 \leq x \leq 1)$ : combined first-principles and experimental study. Adv. Funct. Mater. 24, 4603-4614 (2014).

8. Barpanda, P., Oyama, G., Nishimura, S.-I., Chung, S.-C. \& Yamada, A. A 3.8-V earth-abundant sodium battery electrode. Nat. Commun. 5, 4358 (2014).

9. Komaba, S. et al. Study on the reversible electrode reaction of $\mathrm{Na}_{1}$ ${ }_{x} \mathrm{Ni}_{0.5} \mathrm{Mn}_{0.5} \mathrm{O}_{2}$ for a rechargeable sodium-ion battery. Inorg. Chem. 51, 6211-6220 (2012)

10. Yabuuchi, N. et al. $\mathrm{P} 2$-type $\mathrm{Na}_{\mathrm{x}}\left[\mathrm{Fe}_{1 / 2} \mathrm{Mn}_{1 / 2}\right] \mathrm{O}_{2}$ made from earth-abundant elements for rechargeable Na batteries. Nat. Mater. 11, 512-517 (2012).

11. Shanmukaraj, D. et al. Sacrificial salts: compensating the initial charge irreversibility in lithium batteries. Electrochem. Commun. 12, 1344-1347 (2010).

12. Tarascon, J. M. \& Guyomard, D. The $\mathrm{Li}_{1+x} \mathrm{Mn}_{2} \mathrm{O}_{4} / \mathrm{C}$ rocking-chair system: a review. Electrochim. Acta 38, 1221-1231 (1993).

13. Tang, W. S., Chotard, J.-N. \& Janot, R. Synthesis of single-phase LiSi by ball-milling: electrochemical behavior and hydrogenation properties. J. Electrochem. Soc. 160, A1232-A1240 (2013).

14. Liu, N., Hu, L., Mcdowell, M. T., Jackson, A. \& Cui, Y. Prelithiated silicon nanowires as an anode for lithium ion batteries. ACS Nano 5, 6487-6493 (2011).

15. Ponrouch, A., Goñi, A. R. \& Palacín, M. R. High capacity hard carbon anodes for sodium ion batteries in additive free electrolyte. Electrochem. Commun. 27, 85-88 (2013).

16. Billaud, J. et al. $\mathrm{Na}_{0.67} \mathrm{Mn}_{1-x} \mathrm{Mg}_{x} \mathrm{O}_{2}(0 \leq x \leq 0.2)$ : a high capacity cathode for sodium-ion batteries. Energy Environ. Sci. 7, 1387-1391 (2014).

17. Singh, G. et al. An approach to overcome first cycle irreversible capacity in $\mathrm{P} 2-\mathrm{Na}_{2 / 3}\left[\mathrm{Fe}_{1 / 2} \mathrm{Mn}_{1 / 2}\right] \mathrm{O}_{2}$. Electrochem. Commun. 37, 61-63 (2013).

18. Morcrette, M., Gillot, F., Monconduit, L. \& Tarascon, J.-M. Ballmilling elaboration of Li-based negative electrode materials. Electrochem. Solid-State Lett. 6, A59 (2003).

19. Fullenwarth, J., Darwiche, A., Soares, A., Donnadieu, B. \& Monconduit, L. $\mathrm{NiP}_{3}$ : a promising negative electrode for $\mathrm{Li}$ - and $\mathrm{Na}$-ion batteries. J. Mater. Chem. A 2, 2050-2059 (2014).
20. Qian, J., Wu, X., Cao, Y., Ai, X. \& Yang, H. High capacity and rate capability of amorphous phosphorus for sodium ion batteries. Angew. Chem. Int. Ed. Engl. 52, 4633-4636 (2013).

21. Xie, Y., Su, H., Li, B. \& Qian, Y. Solvothermal preparation of tin phosphide nanorods. Mater. Res. Bull. 35, 675-680 (2000).

22. Jarvis, R. F., Jacubinas, R. M. \& Kaner, R. B. Self-propagating metathesis routes to metastable group 4 phosphides. Inorg. Chem. 39, 3243-3246 (2000).

23. Darwiche, A. et al. Better cycling performances of bulk Sb in Na-ion batteries compared to Li-ion systems: an unexpected electrochemical mechanism. J. Am. Chem. Soc. 134, 20805-20811 (2012).

24. de Boisse, B. M., Carlier, D., Guignard, M., Bourgeois, L. \& Delmas, C. $\mathrm{P} 2$ phase used as positive electrode in $\mathrm{Na}$ batteries. Inorg. Chem. 53, 11197-11205 (2014).

25. Bianchini, M. et al. Comprehensive investigation of the $\mathrm{Na}_{3} \mathrm{~V}_{2}\left(\mathrm{PO}_{4}\right)_{2} \mathrm{~F}_{3}$ $-\mathrm{NaV}_{2}\left(\mathrm{PO}_{4}\right)_{2} \mathrm{~F}_{3}$ system by operando high resolution synchrotron $\mathrm{X}$-ray diffraction. Chem. Mater. 27, 3009-3020 (2015).

26. Bianchini, M. et al. $\mathrm{Na}_{3} \mathrm{~V}_{2}\left(\mathrm{PO}_{4}\right)_{2} \mathrm{~F}_{3}$ revisited: a high-resolution diffraction study. Chem. Mater. 26, 4238-4247 (2014).

27. Jian, Z., Sun, Y. \& Ji, X. A new low-voltage plateau of $\mathrm{Na}_{3} \mathrm{~V}_{2}\left(\mathrm{PO}_{4}\right)_{3}$ as an anode for Na-ion batteries. Chem. Commun. 51, 6381-6383 (2015).

28. Zhao, J. et al. Artificial solid electrolyte interphase protected LixSi nanoparticles: an efficient and stable prelithiation reagent for lithium-ion batteries. J. Am. Chem. Soc. 137, 8372-8375 (2015).

29. Rodríguez-Carvajal, J. Recent advances in magnetic structure determination by neutron powder diffraction. Physica B Condens. Matter 192, 55-69 (1993).

30. Matts, I. L., Dacek, S., Pietrzak, T. K., Malik, R. \& Ceder, G. Explaining Performance-Limiting Mechanisms in Fluorophosphate Na-Ion Battery Cathodes through Inactive Transition-Metal Mixing and First-Principles Mobility Calculations. Chem. Mater. 27, 6008-6015 (2015).

\section{Acknowledgements}

We thank L. Simonin and Y. Chatillon from CEA for sending us the pristine $\mathrm{Na}_{3} \mathrm{~V}_{2}\left(\mathrm{PO}_{4}\right)_{2} \mathrm{~F}_{3}$ materials that we have been using for the present study; Antonella Iadecola and Carlotta Giacobbe for the collection of Synchrotron X-ray diffraction patterns at European Synchrotron Radiation Facility on ID22; and the RS2E' Na-ion task force (C. Masquelier, L. Croguennec) for helpful discussions and J. Kurzman for his critical reading of the paper. Use of the Advanced Photon Source at Argonne National Laboratory was supported by the US Department of Energy, Office of Science, Office of Basic Energy Sciences, under Contract No. DE-AC02-06CH11357.

\section{Author contributions}

B.Z. carried out the synthesis; B.Z., R.D. and J.-M.T. conducted the electrochemical work and designed the research approach; and P.R. produced P2 phase. G.R. analysed the crystal structure and diffraction patterns; A.M.A. carried out the transmission electron microscopy test; and B.Z., G.R. and J.-M.T. wrote the manuscript. All authors discussed the experiments and final manuscript.

\section{Additional information}

Supplementary Information accompanies this paper at http://www.nature.com/ naturecommunications

Competing financial interests: The authors declare no competing financial interests.

Reprints and permission information is available online at http://npg.nature.com/ reprintsandpermissions/

How to cite this article: Zhang, B. et al. Insertion compounds and composites made by ball milling for advanced sodium-ion batteries. Nat. Commun. 7:10308 doi: $10.1038 /$ ncomms10308 (2016)

This work is licensed under a Creative Commons Attribution 4.0 International License. The images or other third party material in this article are included in the article's Creative Commons license, unless indicated otherwise in the credit line; if the material is not included under the Creative Commons license, users will need to obtain permission from the license holder to reproduce the material. To view a copy of this license, visit http://creativecommons.org/licenses/by/4.0/ 